HOW

Volume 29, Number 1, pages 129 - 153

https://doi.org/10.19183/how.29.1.601

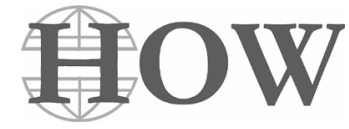

\title{
Inflamed EFL Learning: A Qualitative Study to Explore Factors Affecting EFL Learning
}

\author{
Aprendizaje Exacerbado del Inglés como Lengua Extranjera: \\ Un Estudio Cualitativo para Explorar los Factores \\ que Afectan este Aprendizaje
}

\author{
Hossein Hashemnezhad ${ }^{1}$ \\ Islamic Azad University, Khoy, Iran
}

\begin{abstract}
The purpose of the present study is to conduct a qualitative content analysis to explore factors affecting EFL learning in Iran. To achieve this aim, the researcher carried out face-to-face unstructured interviews with 10 EFL teachers and 12 university students. The researcher used MAX QDA 10 (Qualitative Data Analysis) software to analyze the data. In order to organize the data, open coding, creating categories, and abstraction processes were used. Using the conventional content analysis method, 950 primary codes were collected based on the participants' own statements in the original codes. The researcher immersed himself in the data, listened to the interviews, reviewed transcribed notes several times, excluded overlapping codes and, finally, obtained 640 open codes out of 950 primary codes which were classified into 42 subcategories. This reduction process in all categories and subcategories continued until the researcher reached four main categories and finally one abstracted main theme. The four main categories were factors associated with 'language planning and policy', 'teacher characteristics', 'environmental/social elements', and 'learners' individual characteristics.' It was concluded that the absence of the four mentioned factors leads to 'inflamed EFL learning'. Finally, implications are drawn for language planners and policymakers (LPP) and EFL teachers.
\end{abstract}

Keywords: content analysis, EFL, factors, Iran, qualitative study, speaking

He is an assistant professor of TEFL at the Department of English Language Teaching, Islamic Azad

University, Khoy Branch, Iran. He has 19 years' experience in teaching EFL. His research interests are mainly focused on language teaching as well as assessment. He has published and presented papers in national and international conferences and journals.

h_hashemnezhad2000@yahoo.com

ORCID ID: https://orcid.org/0000-0002-5212-6903

Received: August 4th, 2020. Accepted: October 5th, 2021.

This article is licensed under a Creative Commons Attribution-Non-Commercial-No-Derivatives 4.0 International License. License Deed can be consulted at https://creativecommons.org/licenses/by-nc-nd/4.0. 


\section{Resumen}

El propósito de este estudio es realizar un análisis de contenido cualitativo que explore los factores que afectan el aprendizaje del inglés como lengua extranjera en Irán. Para alcanzar este propósito, se llevó a cabo entrevistas no-estructuradas presenciales con 10 profesores de inglés y 12 estudiantes universitarios. Se usó el software MAX QDA 10 para analizar los datos. Para organizarlos se usaron codificación abierta, creación de categorías y procesos de abstracción. Al usar el método convencional de análisis de contenido, 950 códigos primarios se tomaron de las declaraciones de los participantes en los códigos originales. Al escuchar las entrevistas, revisar varias veces los apuntes trascritos y descartar los códigos duplicados, se obtuvo 640 códigos abiertos, los cuales se clasificaron en 42 sub-categorías. Este proceso de reducción se llevó a cabo hasta que se obtuvo cuatro categorías principales y un tema capital. Las cuatro categorías son los factores asociados con la política y planeación de lengua, las características de los profesores, los elementos sociales y de ambiente y las características individuales de los aprendices. Se concluye que la ausencia de estos cuatro factores conlleva a un aprendizaje exacerbado del inglés como lengua extranjera. Finalmente, las implicaciones del estudio conciernen a los planeadores y hacedores de política de lengua y a los profesores de inglés como lengua extranjera.

Palabras clave: análisis de contenido, inglés como lengua extranjera, factores, Iran, estudio cualitativo, habilidad oral

\section{Introduction}

The significance of learning English as a second or foreign language is very high in the contemporary world of globalization. Along with the strengthening of the position of English for international communication, the development of speaking skills has become increasingly important in the English as a second or foreign language (ESL/EFL) context. Learning to speak in EFL is especially challenging for foreign language learners because it requires more than grammatical rules; it needs the ability to use the language appropriately in social contexts. Finding the factors affecting EFL speaking ability, especially qualitatively, can be effective in obtaining culturally specific information about the values, opinions, behaviors, and social contexts of particular populations.

From the beginning of teaching English in Iran, it was taught at secondary school, high school, and university. During the last decades, English took on a special significance when the Iranian government felt an emergent need to increase its international role in the world.

130 The number of schools, institutes, universities, both private and non-private, was increased. Despite already teaching English courses at secondary school and high school, it seems that English language learning problems still exist in Iran. Although a number of researchers have investigated factors affecting the EFL speaking ability, findings are not yet conclusive.

Furthermore, almost no study has followed the same purpose qualitatively through content analysis. The present study tries to bridge the gap between reality and truth; in other words, to make a contrast between what really and quantitatively is and what truthfully and 
qualitatively might be true. The purpose of the present study is to conduct a qualitative content analysis method to explore factors affecting EFL learning, especially EFL speaking from the perspectives of EFL teachers and students in different disciplines in West Azerbaijan province, Khoy, Iran. Using this method, the researcher goes beyond some statistically appealing numbers and rather sees the social reality in a subjective but scientific manner.

\section{Review of the Related Literature}

\section{Theoretical Background}

It becomes clear to us that speaking or oral communication has been considered an important language skill for second/ foreign language learners. It is also apparent that, naturally, to speak is not only to convey a message that someone else needs or to get information which has not been known, but, more importantly, to interact with other people. Learning to speak English requires more than knowing its grammatical and semantic rules. Students need to know how native speakers use the language in the context of structured interpersonal exchange. In other words, as Schumin (2002) stated, "effective oral communication requires the ability to use the language appropriately in social interactions" (p. 204). Due to the importance of the notion of communicative competence, a number of language and language teaching experts (e.g., Canale \& Swain, 1980; Hymes, 1971) elaborated on the nature of this concept. Hymes's (1971) theory of communicative competence consists of the interaction of grammatical, psycholinguistic, sociolinguistic, and probabilistic language components. For Canale and Swain (1980), communicative competence includes four components of competence: grammatical competence, discourse competence, sociolinguistic competence, and strategic competence. In the context of foreign language learning, Canale and Swain's interpretation of communicative competence has been frequently referred to.

English language teaching in the Islamic Republic of Iran, especially after the Islamic Revolution in 1979, was faced with significant challenges due to the political and diplomatic relations between Iran and the United States as well as the conservative view of the Iranian people towards the United States and the problems between the two countries. But in recent years, despite the possibility of teaching other foreign languages such as Russian, Chinese, French, Italian, German, Spanish, etc., much emphasis has been placed on teaching English as a foreign language in Iran.

Because English language teaching is considered a tool for globalization and personal development, in recent years, much emphasis has been placed on teaching this language in schools and universities, both public and private, and even informally in primary schools. Today, after several decades of the Islamic Revolution in Iran, and despite the emphasis on teaching English and creating a suitable platform for this, there are still many problems in 
teaching English in general (Farhady, Hezaveh, \& Hedayati, 2010; Iranmehr \& Davari, 2018) and the speaking skill in particular (Afshar \& Asakereh, 2016; Mahmoudikia \& Ahmadi, 2020; Sadeghi \& Richards, 2015). In general, English language teaching problems in Iran can be attributed to inadequate curriculum, a low number of capable teachers, traditional education, political, cultural, social, historical, and ideological factors (Aghagolzadeh \& Davari, 2017; Farhady, et al., 2010). Sadeghi and Richards (2015) also added that the nature of the speaking skill is generally misunderstood by both EFL teachers and teacher trainers in language institutes in Iran.

Philosophy is the way individuals think about human phenomenon and research. There are two major philosophical traditions, positivism and post-positivism (naturalism). In education, the quantitative studies may be classified under positivism while the qualitative approach research is described based on naturalism. One of the principal differences between quantitative and qualitative methods, as Mack, Woodsong, Macqueen, Guest, and Namey (2005) proposed, refers to the term flexibility. Qualitative methods are typically more flexible. They ask mostly 'open-ended' questions that are unique to each participant. There are different classifications for types of qualitative studies. Content analysis is only one out of various kinds of qualitative studies which can be done both quantitatively and qualitatively. Zhang and Wildemuth (2009) compared qualitative and quantitative content analysis and stated that quantitative content analysis seems to be more deductive but qualitative content analysis is mainly inductive, grounding the examination of topics and themes, as well as the inferences drawn from them in the data. Qualitative content analysis, in some cases, attempts to generate theory (as a basis for grounded theory). Regarding sampling techniques, quantitative content analysis uses the/a random sampling procedure while qualitative content analysis usually applies some purposively selected texts. Also, the quantitative approach produces numbers that can be manipulated with various statistical methods. By contrast, the qualitative approach usually produces descriptions or typologies, along with expressions from subjects reflecting how they view the social world. Finally, qualitative content analysis considers unique themes that indicate the range of the meanings of the phenomenon rather than the statistical significance of the occurrence of particular texts or concepts.

Different classifications for methods of data collection in qualitative studies were introduced (see, e.g., Atkinson \& Ramanathan, 1995; Bolderstone, 2012; Cresswell, 2003; Woods, 2006). The interview, as a data collection method, has three common types: highly structured, semi-structured, and unstructured (Hancock, 2002; Nunan, 1992). In structured interviews, like questionnaires, the interviewer asks a set of scheduled questions in advance. Semi-structured interviews, which sometimes refer to focused interviews, involve a series of open-ended questions. The in-depth or unstructured interview lacks a high and fixed structure and is more directed by the responses of the interviewee rather than the agenda of the researcher. That is, a restricted set of questions are discussed and the interviewer 
forms the questions on the bases of the interviewee's previous responses. In this type of interview, the interviewer has little control over the interview and it seems to have a relatively unpredictable direction.

\section{Empirical Studies}

In his study, Schumin (2002) identified (a) age or maturational constraint, (b) the aural medium, (c) sociocultural factors, and (d) affective factors as four key themes affecting EFL speaking ability. Derwing, DeCorby, Ichikawa, and Jamieson (1999) also carried out a qualitative study with 15 former ESL students and six mainstream classroom teachers to discover their perceptions of their experiences in ESL. Data analysis showed four main themes of (a) the age cap, (b) the school climate, (c) personal relationships with peers and teachers, and (d) personal goals.

Several studies explained how and why policies have certain effects in particular contexts. Cummins (1986, as cited in Wong, 1996) proposed a four-element framework for empowering minority students as a useful starting point for formulating institutional policies that support language minority students. Donato and Terry (1995) asked several foreign language specialists to share their opinions on the evolution of foreign language learning. They advocated five different factors affecting EFL learning, to wit: (a) early language instruction, (b) implementing special programs, (c) changes that affect early adolescents, (d) implementing language learning as a continual process, and finally, (e) the development of standards.

Regarding the effect of teacher characteristics on EFL learning, Li (2001) carried out a case study approach to investigate Korean teachers' perceptions of the implementation of CLT. EFL teachers' perceptions were collected through a pilot study, a written questionnaire, and interviews. Findings revealed six teacher-related problems in the implementation of CLT: (a) deficiency in spoken English, (b) deficiency in strategic and sociolinguistic competence in English, (c) lack of training in CLT, (d) few opportunities for retraining in CLT, (e) misconceptions about CLT, and (f) little time and expertise for developing communicative materials.

Chen (2012) conducted a study to find the favorable and unfavorable characteristics of EFL teachers, as perceived by Tai university students. The results reported two main themes: personal trait-related characteristics and classroom teaching-related characteristics. Concerning the impact of social environmental factors on English learning, Fathman (1976) conducted a study to examine the effect of certain environmental variables upon learning to speak English as a second language. She mentioned seven environmental variables as: 'grade in school', 'hours spent in ESL class', 'number of foreign students speaking same native language in school attended', 'number of foreign students in school attended', 'size of ESL class', 'teaching emphases of ESL class', 'type of instruction in class', and 'schools.' Kovács (2011), in the same vein, proposed two social environmental circles. The first is the 
immediate micro-environment that consists of family and friends. The second, outer circle, is labelled the exo-environment which comprises the workplace, the language teacher, and the language school.

In order to examine the importance of individual differences as regards EFL learning, Ellis (1994) compared three outstanding classifications for individual learner differences (Altman, 1980; Larsen-Freeman \& Long, 1991; Skehan, 1989, all cited in Ellis, 1994). He separated the term learner strategies and put them in different classifications. Ehrman, Leaver, and Oxford (2003) classified individual learner differences into the three categories of 'learning style', 'learning strategies' and 'affective variables.' Dornyei and Skehan (2003) considered 'foreign language aptitude', 'learning style', 'learning strategies', and 'motivation' as four major variables of individual learner differences.

Finally, the present qualitative study sought to explore the following research question: What are the factors affecting EFL learning, specifically the speaking ability from the perspectives of EFL teachers and students in Iran?

\section{Methodology}

\section{Data Collection}

To collect the data, the researcher utilized the face-to-face method of the unstructured interview. Following Bolderstone (2012), McNumara (2009), and Turner (2010), the researcher used the following five steps as the backbone for research interviews.

\section{Selecting the Participants}

The researcher used purposive sampling. The last decision on sample numbers was based on evidence of data saturation. The interviewer reached this saturation point when he interviewed 10 EFL teachers and 12 university students. Only those potential participants that had insight, understanding, interest, and intent on the research topic were selected. The research participants had the following demographic characteristics: Teachers were all from the same city and ranged in age from 35 to 48. Sixty percent of them were female and 40\% were male. Only 20\% held Ph.D.'s and the rest had M.A.'s in TEFL. They all had teaching experience at university, and $40 \%$ had previous teaching experience at secondary and high school levels. Students were all from the same city and ranged in age from 19 to 27. Fifty percent of them were female and 50\% were male. All students were B.A. and B.S. students in EFL, nursing, management, and mechanics majors. On average, they all attended supplementary English conversation classes for two to six semesters. 


\section{Preparation for the Interview}

Probably the most important phase of the interview process is preparation. First, the interviewer made an appointment with each participant at a time which suited them. A quiet, private, and comfortable place was prepared and the recording equipment was checked beforehand. In order to build a rapport, the interviewer provided tea and water, especially when he allowed some small talk before initiation of the interview. He gave a brief but necessary explanation about the research. All the participants were reminded of their right to leave the interview session and withdraw from the study at any time as part of the informed consent process. In short, McNamara's (2009) eight principles were applied to the preparation stage of interviewing.

\section{Conducting a Pilot Test}

Piloting is a key aspect of every research. According to Kvale (2007), piloting helps the researcher to determine the probable limitation and weak points within the interview design and lets the interviewer make necessary revisions prior to the study. In the present study, piloting helped the researcher to exclude two participants who showed less interest and provided less information to the interviewer.

\section{Taking an Appropriate Role for the Interviewer}

The researchers followed Bolderstone's (2012) five suggestions for adapting an effective role for the interviewer. The interviewer tried to:

1. Be more a listener rather than a corrector or an educator.

2. Pay much attention and listen attentively.

3. Avoid turning the interview into a counseling session.

4. Not be afraid of silence. Sometimes interviewees need time and silence to organize and reflect on the topic.

5. Avoid demonstrating bias. He tried to be more neutral and avoided comments such as 'good', 'excellent', etc.

\section{Timing}

The length of each interview depends on a number of factors, including the type of interview, complexity of questions, the number of key questions in the interview, the interviewee's familiarity and previous experience with interview, and the size of the group. 
Considering all the above-mentioned factors, on average, the researcher conducted a 45-minute interview with each participant.

\section{Data Analysis}

Analysis can be an ongoing process that is conducted concurrently with gathering the data (Creswell, 2009). Following Tesch (1990), when the researcher immersed himself in the data and was satisfied that the text had become accessible to him, he delineated all meaningful units throughout the entire interview transcription, decided which ones were relevant to the research questions, then bound the meaning units that contained them. The present study used 'conventional qualitative inductive content analysis', in which coding categories are derived directly and inductively from the raw data.

\section{Coding}

Elo and Kyngas' (2008) coding steps as open coding, creating categories, and abstraction were taken at this stage. During the open coding stage, notes and headings were written in the text while reading it. As Hsieh and Shannon (2005) stated, after reading meticulously the entire written material several times, the interviewer should write down in the margin as many headings as necessary to describe all aspects of the content. The collected headings formed the coding sheets and thus categories were freely generated. Following McCain (1988) and Burnard (1991), after this open coding process, the lists of categories were grouped under higher order headings (both cited in Elo \& Kyngas, 2008). When formulating categories inductively, the researcher decided to put suitable things in the similar categories. Abstraction means formulating a general description of the research topic through generating categories (Burnard, 1996; Robson, 1993; both cited in Elo \& Kyngas, 2008). Then each category was labeled using content-characteristic words. Subcategories with resembling events and incidents were grouped together as categories, and categories were grouped as main categories. The abstraction process continued as far as was reasonable and possible.

\section{Trustworthiness (Rigor)}

136 Trustworthiness is a term for establishing validity and reliability in qualitative research. It indicates if the research accurately represents the experiences of participants. Lincoln and Guba (1985) outlined the assumptions of trustworthiness in Table 1 and contrasted them with their non-qualitative counterparts. 
Table 1. Comparison of Trustworthiness and Validity Criteria

\begin{tabular}{|l|l|}
\hline \multicolumn{1}{|c|}{ Qualitative } & \multicolumn{1}{c|}{ Non-Qualitative } \\
\hline Credibility & Internal Validity \\
\hline Transferability & External Validity \\
\hline Dependability & Reliability \\
\hline Confirmability & Objectivity \\
\hline
\end{tabular}

Krefting (1991) added some more criteria to Guba's (1981, as cited in Krefting, 1991) and Lincoln and Guba's (1985) list of strategies. (Table 2) illustrates some strategies used in the study.

Table 2. Summary of Strategies to Establish Trustworthiness

\begin{tabular}{|l|l|l|}
\hline \multicolumn{1}{|c|}{ Strategy } & \multicolumn{1}{|c|}{ Criteria } & \multicolumn{1}{c|}{ Description } \\
\hline $\begin{array}{l}\text { Credibility } \\
\text { (Are the reported } \\
\text { findings true?) }\end{array}$ & $\begin{array}{l}\text { Prolonged and } \\
\text { varied field experience }\end{array}$ & $\begin{array}{l}\text { Allows the researcher to check } \\
\text { perspectives and allows the informants } \\
\text { to become accustomed to the } \\
\text { researcher, trusting relationships }\end{array}$ \\
\hline Member checking & $\begin{array}{l}\text { Data, analytic categories, interpretations, } \\
\text { and conclusions are tested with members } \\
\text { of those stake- holding groups from } \\
\text { whom the data were originally collected. }\end{array}$ \\
\hline $\begin{array}{l}\text { Transferability } \\
\text { (whether findings can } \\
\text { "fit" for settings beyond } \\
\text { that of particular study) }\end{array}$ & Dense description & $\begin{array}{l}\text { The reframing of questions, repetition } \\
\text { of questions, or expansion of } \\
\text { questions on different occasions. }\end{array}$ \\
\hline $\begin{array}{l}\text { Dependability } \\
\text { (Consistency) refers } \\
\text { to the stability of } \\
\text { data over time and } \\
\text { under conditions }\end{array}$ & $\begin{array}{l}\text { It is critical that researchers provide } \\
\text { dense background information about } \\
\text { the informants and the research context } \\
\text { and setting to allow others to assess } \\
\text { how transferable the findings are. }\end{array}$ \\
\hline
\end{tabular}




\begin{tabular}{|l|l|l|}
\hline \multicolumn{1}{|c|}{ Strategy } & \multicolumn{1}{c|}{ Criteria } & \multicolumn{1}{c|}{ Description } \\
\hline $\begin{array}{l}\text { Confirmability } \\
\text { refers to the objectivity } \\
\text { or neutrality (free } \\
\text { from bias) } \\
\text { of the data. Guba } \\
\text { viewed neutrality } \\
\text { not as a researcher } \\
\text { objectivity but as data } \\
\text { and interpretational } \\
\text { confirmability. }\end{array}$ & Confirmability audit & $\begin{array}{l}\text { This strategy involves an external } \\
\text { auditor attempting to follow through } \\
\text { the natural history or progression of } \\
\text { events in a project to try to understand } \\
\text { how and why decisions were made } \\
\text { In addition, auditability suggests that } \\
\text { another researcher could arrive at } \\
\text { comparable conclusions given the }\end{array}$ \\
\hline
\end{tabular}

Note. From “Naturalistic inquiry," by Y.S. Lincoln \& E. G. Guba (1985).

\section{Results}

As was mentioned before, the researcher reached this saturation point when he ended conducting interviews with $10 \mathrm{EFL}$ teachers and 12 university students. The researcher used MAX QDA 10 (Qualitative Data Analysis) software to analyze the data. The process of data collection and data analysis was conducted concurrently. In order to organize the data in the present inductive content analysis, the researcher used open coding, creating categories, and abstraction processes. Using the/a conventional content analysis method, 950 primary codes were collected based on the participants' own statements in the original codes. The researcher was immersed in the data, listened to the interviews; reviewed handwritten notes several times, excluded overlapping codes, and finally obtained 640 open codes out of 950 primary codes. The researcher meticulously read the open codes over and over, classified them in similar and condensed categories until he reached 46 subcategories. This reduction process in all analysis units and in all categories and subcategories continued until the researcher reached one abstracted main theme.

The 43 subcategories of content analysis were grouped under the 4 main categories of: Barriers associated with 'language planning and policy', 'teacher characteristics', 'environmental/social elements', and 'learners' individual characteristics.'

\section{First Category (Barriers Associated with Language Planners and Policymakers)}

Language Planning and Policymaking (LPP) determines the overall aims of the curriculum and is influenced by special interest groups. Policymaking encompasses 'curriculum design' 
and 'instructional design'. Students' achievements are influenced by much more than any individual teacher. In the present study, factors related to this category are classified under nine factors such as: Aging or maturational factors, inappropriate content in books, insufficient number of teaching hours, lack of supervision or monitoring of teaching and learning processes by the relevant authorities... (For more information, see Table 8 below).

In order to be familiar with interviewees' statements, some examples are included in this section. A university student stated that: "If I learned EFL from primary school, I would become more interested in higher levels and the lessons would be more attractive to me" (Aging or maturational barrier). An EFL teacher said: "Unfortunately, the onset of EFL learning in Iran is secondary school. Since learning does not start from the beginning, we're actually missing out on the best age (7-14) to learn" (Aging or maturational barrier). A university student complained of an insufficient number of EFL teaching hours as: "EFL teaching hours should be more at all levels which unfortunately are too few. Contrary to the expectations, teaching hours in university are not enough either" (insufficient number of EFL teaching hours). Another university student majoring in mechanics stated that: " $I$ was never pleased with English teaching in university. I read only two books during four years. A 3-credit general English and a 2-credit ESP and just two or three lessons from each" (insufficient number of EFL teaching hours).

\section{Second Category (Barriers Associated with Teachers)}

Teachers play essential roles in EFL teaching. They are directly affected by educational policy and may affect any nationally-instituted educational policy. Teachers' knowledge, skills, and their personal traits may affect the whole process of language learning as well as teaching. There are 11 factors classified under this category such as: Poor or inappropriate teaching methods, use of force, inadequate knowledge or lack of strong will to teach or speak English, lack of enough understanding of learners... (For more information, see Table 8 below).

In order to be familiar with interviewees' statements, some examples are included in this section. A university student revealed that: "A significant number of my EFL teachers lacked enough energy, interest, and familiarity with English teaching and innovative teaching methods as well. Some of them were not even able to speak English or did not want to talk" (Inadequate knowledge or lack of strong will to teach or speak English). A university student believed that: "My EFL teachers put much emphasis on English to Persian translation. This causes students to be layy. If translation, as a teaching or testing technique, is necessary in the class, it should be an English-to-English translation. This increases learners' concentration and expands the range of vocabulary as well" (Use of traditional methods in both teaching and testing). Another university student added that: "My EFL teachers, at all levels, were too text bound. They did not use supplementary books and materials such as English newspapers. Newspapers make the students more familiar with new words and daily expressions" (Absence of supplementary books along with other main course book). An EFL teacher 
stated that: "I am still influenced by traditional methods. I highly emphasize reading and grammar and ignore listening skill" (Poor or inappropriate teaching methods).

\section{Third Category (Barriers Associated with Social/ Environmental Factors)}

Social environment plays a vital role in individuals' cognitive and affective developments. This idea was first proposed by Bronfenbrenner (1979, as cited in Kovács, 2011). Kovács (2011) reconstructed this idea and designed a theoretical model for adult EFL learners. There are 16 factors classified under this category such as: Lack of enough equipment and teaching aids, failure of national media to broadcast English programs, inability of national media to produce English programs to fit the local culture, inappropriate perspective of English language... (For more information, see Table 8).

In order to be familiar with interviewees' statements, some examples are included in this section. A university student revealed that: "I remember when we were talking about English language; everyone said that it was very difficult. Perhaps this was due to their unpleasant memories of English learning. Or maybe because they took it as an alien language" (Induction of the common view that English is an alien language that is difficult to learn). An M.A. university student believed that: "Along with many language institutions available now, absence of a valid language institute with an integrated language system got more sense" (Absence of standard and reputable language institutions in all cities and if there are any, they are still problematic). An experienced EFL teacher declared that: "I have got enough teaching experience at various levels. I feel that multiplicity of English language institutes distributed language learners in different institutions. Our placement tests are not taken as good entrance criteria for different levels. I remember some managers who were just lining their classes with learner of different language levels" (Absence of standard and reputable language institutions in all cities and if there are any, they are still problematic).

\section{Fourth Category (Barriers Associated with Learners' Individual Characteristics)}

It is obvious that people differ from each other. How and why, they differ is not clear and is the subject to individual differences. Individual differences are regarded as the key element in foreign language learning. Different classifications for individual differences were proposed by various scholars (Dornyei \& Skehan, 2003; Ehrman, Leaver, \& Oxford, 2003; Ellis, 1994). There are five factors classified under this category such as: Individuals' lack of interest and motivation, individuals' lack of English aptitude, individuals' lack of sufficient time to learn EFL, individuals' absence of 'need' to learn EFL... (For more information, see Table 8). 
In order to be familiar with interviewees' statements, some examples are included in this section. An M.A. university student stated that: "I lack the motivation to learn and speak the language, perbaps due to absence of tourism in Iran, or the inability of my family to travel abroad. The mentioned factors can help learners to become motivated" (Individuals' lack of interest and motivation). The interviewer asked an experienced EFL teacher: "I: With all the problems and barriers that exist in language learning, there are still people who learned the language well and have a good command of it. In your opinion, what factors led to the development of such successful English language learners in Iran? T: Personal interests can be one of the effective factors in language learning. I had some students whose parents or classmates spoke English at home or school, it highly motivated individuals to learn. Individual aptitude can be another effective factor too. But I rarely had such distinctive students with high English aptitude. I feel environmental factors are more effective than individual factors. Maybe individual factors are influenced by environmental factors (Lack of interest and aptitude).

\section{Discussion}

The purpose of the present study, as mentioned earlier, was to explore factors affecting EFL learning, especially EFL speaking from the perspectives of EFL teachers and students in Iran. To achieve that goal, the researcher conducted a qualitative content analysis method. To do so, the researcher carried out face-to-face interviews with different participants. Data analysis revealed 43 subcategories grouped under 4 main categories: a) 'language planning and policy', b) 'teacher him/herself', c) 'environmental/social elements', and d) 'learners' individual characteristics'.

In a study to find factors affecting EFL speaking ability, Schumin (2002) considered (a) age or maturational constraint, (b) aural medium, (c) socio-cultural factors, and (d) affective factors as four key themes affecting EFL speaking ability. She argued that EFL learners should begin in early childhood through natural exposure. Second, listening skill should be taught and emphasized before speaking proficiency. In order to have a successful EFL experience, Schumin (2002) stated that individuals must know how the language is used in the social content. Finally, affective factors such as learners' emotions, self-esteem, anxiety, motivation, etc. have significant influence on one's success or failure in language learning process.

Derwing, DeCorby, Ichikawa, and Jamieson (1999) carried out a qualitative study with 15 former ESL students and six mainstream classroom teachers to discover their perceptions of their experiences in ESL. Data analysis showed four main themes: (a) the age cap, (b) the school climate, (c) personal relationships with peers and teachers, and (d) personal goals.

As Table 3 below illustrates, in some respects, the findings of the current study are inconsistent with the findings of other studies and are in some ways more complete. Barriers to language learning are not exclusively related to environmental and affective factors. 
Instead, those related to LPP and teaching methods/techniques used in the class can have a significant impact on language learning, which have been overlooked in Derwing et al. (1999) and Schumin's (2002) studies. Also, the age factor is only one of several subcategories under LPP which were investigated in the two mentioned studies just as a single case.

Table 3. Main Themes Comparison

\begin{tabular}{|l|l|l|}
\hline \multicolumn{1}{|c|}{ Schumin (2002) } & $\begin{array}{c}\text { Derwing, DeCorby, Ichikawa, } \\
\text { and Jamieson (1999) }\end{array}$ & Present study \\
\hline $\begin{array}{l}\text { - age or maturational } \\
\text { constraint }\end{array}$ & - the age cap & - language planning and policy \\
\hline- aural medium & - the school climate & - teacher him/herself \\
\hline- sociocultural factors & $\begin{array}{l}- \text { personal relationships } \\
\text { with peers and teachers }\end{array}$ & - environmental/social elements \\
\hline- affective factors & - personal goals & $\begin{array}{c}\text { learners' individual } \\
\text { characteristics }\end{array}$ \\
\hline
\end{tabular}

\section{Language Planning and Policymaking}

Data in Table 4 compared subcategories of LPP in the present study with two other known studies. Several research studies explained how and why policies have certain effects on certain influences in particular contexts.

The aim of every study should be both obtaining concrete and understandable findings for all and having a practical and operational function. Contrary to Cummins's (1986, cited in Wong, 1996), Donato and Terry's (1995) research findings, which seemed somewhat intangible, subjective and too general, the present study described the subcategories underlying LPP in a more concrete and detailed way.

Findings of the present study are consistent with those reported by Webster (2019), who conducted a study to examine the practical knowledge development of four early career English language teachers. It was concluded that there is a lack of development in early career teachers' practical knowledge of teaching the speaking skill. The findings further highlighted the need for some educational institutions to improve the quality of teaching and change the static nature of language (Macalister, 2018) into a dynamic one. Findings of the present study are also in line with Aghagolzadeh and Davari (2017) and Sadeghi and Richards (2015). They regarded the socio-political, cultural, and ideological issues as key factors affecting EFL learning in Iran. Sadeghi and Richards (2015) further added that the nature of developing speaking skills is misunderstood by both EFL teachers and teacher trainers in language institutes in Iran. 
Table 4. Taxonomy for Language Planning and Policy

\begin{tabular}{|c|c|c|}
\hline Cummins's (1986) & Donato and Terry's (1995) & Present Study \\
\hline $\begin{array}{l}\text { School should take an } \\
\text { additive rather than a } \\
\text { subtractive view toward } \\
\text { minority students' } \\
\text { language and culture. }\end{array}$ & $\begin{array}{l}\text { Advocating early } \\
\text { language instruction }\end{array}$ & Aging or maturational factors \\
\hline $\begin{array}{l}\text { Second, school should } \\
\text { favor community } \\
\text { participation in the school }\end{array}$ & $\begin{array}{l}\text { Implementing some } \\
\text { special programs such as } \\
\text { immersion programs }\end{array}$ & Inappropriate content of books \\
\hline $\begin{array}{l}\text { Pedagogy should be } \\
\text { reciprocal and interactive }\end{array}$ & $\begin{array}{l}\text { Taking into account } \\
\text { some changes that affect } \\
\text { early adolescents }\end{array}$ & $\begin{array}{l}\text { Insufficient number } \\
\text { of teaching hours }\end{array}$ \\
\hline \multirow[t]{6}{*}{$\begin{array}{l}\text { Assessment should support } \\
\text { language minority students }\end{array}$} & $\begin{array}{l}\text { Viewing and implementing } \\
\text { language learning as a } \\
\text { continual process }\end{array}$ & $\begin{array}{l}\text { Lack of supervision or } \\
\text { monitoring of teaching } \\
\text { and learning process by } \\
\text { the relevant authorities }\end{array}$ \\
\hline & $\begin{array}{l}\text { The development of standards } \\
\text { in order to align all levels of } \\
\text { education and orient them } \\
\text { toward the same goals. }\end{array}$ & $\begin{array}{l}\text { Mere use of Persian texts in } \\
\text { other courses and ignoring } \\
\text { the use of English books }\end{array}$ \\
\hline & & $\begin{array}{l}\text { Ineffective or lack of training } \\
\text { courses for EFL teachers }\end{array}$ \\
\hline & & $\begin{array}{l}\text { Ignoring Listening and Speaking } \\
\text { skills in acquisition order }\end{array}$ \\
\hline & & $\begin{array}{l}\text { Gap between EFL learning } \\
\text { resources/equipment and } \\
\text { current needs of learners }\end{array}$ \\
\hline & & $\begin{array}{l}\text { Overlooked priorities: The } \\
\text { vagueness of 'what should } \\
\text { be learned' \& 'how should it } \\
\text { be organized for teaching' }\end{array}$ \\
\hline
\end{tabular}




\section{Characteristics of Teachers}

The personal characteristics of the teacher are one of the most important and influential factors in learning a foreign language. Various factors such as the teacher's personal factors, his/her emotional and communication characteristics, pedagogical factors, etc., can be considered as influential factors in foreign language teaching and may distinguish successful and unsuccessful EFL learners. These characteristics can be an important factor in increasing the motivation and attitude of learners towards learning a foreign language (Chen, 2012; Liando, 2010). In the present study, the personal characteristics of the teacher are divided into 11 subcategories (for more information, see Table 8 below).

Findings of the present study are consistent with Li's (2001) and Chen's (2012) studies in which six major constraints and two major themes are caused by the teachers respectively. Furthermore, they include more general and new factors as barriers affecting EFL which had not been mentioned in previous studies. Sometimes teachers have enough knowledge of EFL teaching but they lack a strong will to teach or speak English. This study has also raised a number of learning problems that are specific to the learning/teaching at the universities; for example, inadequate teaching and failure to follow rubrics in the universities or a mismatch of ESP books with different trends in a discipline. Findings of the present research study are also in line with Afshar and Asakereh (2016) and Sadeghi and Richards (2015). They regarded the proficiency level of teachers as a key factor affecting EFL learning in Iran.

Table 5. Taxonomy for Language Teachers

\begin{tabular}{|l|l|l|}
\hline \multicolumn{1}{|c|}{ Li (2001) } & \multicolumn{1}{|c|}{ Chen (2012) } & \multicolumn{1}{c|}{ Present Study } \\
\hline $\begin{array}{l}\text { deficiency in } \\
\text { spoken English }\end{array}$ & $\begin{array}{l}\text { - personal trait- related } \\
\text { characteristics }\end{array}$ & $\begin{array}{l}\text { poor or inappropriate } \\
\text { teaching methods }\end{array}$ \\
\hline $\begin{array}{l}\text { deficiency in strategic } \\
\text { and sociolinguistic } \\
\text { competence in English }\end{array}$ & - emotions & use of force \\
\hline $\begin{array}{l}\text { lack of training in CLT } \\
\text { few opportunities for } \\
\text { retraining in CLT }\end{array}$ & - kindness & $\begin{array}{l}\text { inadequate knowledge or lack of a } \\
\text { strong will to teach or speak English }\end{array}$ \\
\hline $\begin{array}{l}\text { misconceptions } \\
\text { about CLT }\end{array}$ & - lenience & $\begin{array}{l}\text { lack of enough understanding } \\
\text { of learners }\end{array}$ \\
\hline
\end{tabular}




\begin{tabular}{|c|c|c|}
\hline $\mathrm{Li}(2001)$ & Chen (2012) & Present Study \\
\hline \multirow{6}{*}{$\begin{array}{l}\text { little time and } \\
\text { expertise for } \\
\text { developing } \\
\text { communicative } \\
\text { materials }\end{array}$} & - responsibility & $\begin{array}{l}\text { inadequate teaching and failure } \\
\text { to follow rubrics in university }\end{array}$ \\
\hline & $\begin{array}{l}\text { - classroom teaching } \\
\text { related characteristics }\end{array}$ & $\begin{array}{l}\text { mismatch of ESP books with } \\
\text { different trends in a discipline }\end{array}$ \\
\hline & - lesson delivery & teachers' lack of creativity \\
\hline & - language used in teaching & $\begin{array}{l}\text { emphasis on learners' local } \\
\text { errors instead of global errors }\end{array}$ \\
\hline & $\begin{array}{l}\text { - classroom activity } \\
\text { organization }\end{array}$ & $\begin{array}{l}\text { use of traditional methods in } \\
\text { both teaching and testing }\end{array}$ \\
\hline & $\begin{array}{l}\text { - classroom atmosphere } \\
\text { creation }\end{array}$ & $\begin{array}{l}\text { absence of supplementary materials } \\
\text { along with main course book }\end{array}$ \\
\hline
\end{tabular}

\section{Environmental/Social Factors}

Environmental/social factors is the label given to the third theme which emerged from the research data. As Table 6 below illustrates, the findings of the present research are consistent with those of previous studies, especially with Kovács (2011). However, it is more detailed and includes more various factors as barriers affecting EFL. The focus is more on real life environment rather than private environments. However, findings in this study are less consistent than those of Fathman (1976). 'Grade in school' which refers to age of learners is a variable labeled as environmental by Fathman (1976). The present study regards this factor as one of the major elements associated with LPP. That is, the onset of second or foreign language learning is more a decision-making concern for language planners and policymakers. Also, the findings of the present study are in line with other studies, especially with Niu, Lu, and You (2018). They did an exploratory research project to examine EFL learners' oral language learning experiences from a socio-cultural perspective. The collected data through interviews and written journals revealed 13 socio-cultural resources which fell into the four categories of artifacts, rules, community, and roles. Among the mentioned resources, 'school' was the most frequent factor followed by 'internet', 'examination', and 'contests.' The findings of the present study also confirm that which was concluded by Butler and Le (2017). They reported that parental income and their educational level are positively related to students' English performance. Findings of the present study are also in line with some studies conducted in the Iranian context (Afshar \& Asakereh, 2016; Aghagolzadeh \& Davari, 2017; Farhady, et al., 2010; Sadeghi \& Richards, 2015). 
Table 6. Taxonomy for Environmental/Social Factors

\begin{tabular}{|c|c|c|}
\hline Fathman (1976) & Kovács (2011) & Present Study \\
\hline - Grade in school & - micro-environment & $\begin{array}{l}\text { - lack of enough equipment } \\
\text { and teaching aids }\end{array}$ \\
\hline - Hours spent in ESL class & - family & $\begin{array}{l}\text { - failure of national media to } \\
\text { broadcast English programs }\end{array}$ \\
\hline $\begin{array}{l}\text { Number of foreign } \\
\text { students speaking } \\
\text { same native language } \\
\text { in school attended } \\
\end{array}$ & - friends & $\begin{array}{l}\text { - inability of national media to } \\
\text { produce English programs } \\
\text { to fit the local culture }\end{array}$ \\
\hline $\begin{array}{l}\text { - Number of foreign } \\
\text { students in school } \\
\text { attended }\end{array}$ & - exo-environment & $\begin{array}{l}\text { - inappropriate perspective } \\
\text { of English language }\end{array}$ \\
\hline - Size of ESL class & - workplace & $\begin{array}{l}\text { - } \text { absence of standard and } \\
\text { reputable language institutions } \\
\text { in all cities and if there are } \\
\text { any, they are still problematic }\end{array}$ \\
\hline $\begin{array}{l}\text { - Teaching emphasis } \\
\text { of ESL Class }\end{array}$ & - language teacher & $\begin{array}{l}\text { - non-standardized } \\
\text { English language tests } \\
\text { with improper goals }\end{array}$ \\
\hline $\begin{array}{l}\text { - Type of instruction } \\
\text { in class }\end{array}$ & - language school & $\begin{array}{l}\text { - lack of tourists and the } \\
\text { tourism industry }\end{array}$ \\
\hline \multirow[t]{6}{*}{ - Schools } & & $\begin{array}{l}\text { - lack of people familiar with the } \\
\text { English language around them }\end{array}$ \\
\hline & & $\begin{array}{l}\text { - lack of enough employment } \\
\text { for English graduates }\end{array}$ \\
\hline & & $\begin{array}{l}\text { - un-affordability of people } \\
\text { to travel abroad }\end{array}$ \\
\hline & & $\begin{array}{l}\text { - confidence of EFL learners } \\
\text { in successfully and easily } \\
\text { passing higher level English } \\
\text { courses in future }\end{array}$ \\
\hline & & $\begin{array}{l}\text { - lack of a supportive system for } \\
\text { both teaching and managing } \\
\text { EFL learning programs }\end{array}$ \\
\hline & & $\begin{array}{l}\text { - lack of proper educational } \\
\text { environment especially } \\
\text { in language institutes }\end{array}$ \\
\hline
\end{tabular}




\section{Learners' Individual Characteristics}

'Individual learner differences' is another influential theme affecting foreign language learning. Different scholars provided various classifications for individual learner differences. As Table 7 below illustrates, research findings considered individuals' lack of interest and motivation, individuals' lack of English aptitude, lack of sufficient time to learn EFL, individuals' absence of 'need' to learn EFL, and individuals' shyness when speaking English as five subcategories for individual learner differences. The research findings seem to be inconsistent with those of Ehrman, Leaver, and Oxford (2003) and Dornyei and Skehan (2003). The last three out of five mentioned variables are some newly-included personal factors which were overlooked by the other two studies. Also, findings of the present study are in line with De Burgh-Hirabe (2019), who conducted a qualitative study to find the motivation types and learning experience of Japanese as EFL learners in New Zealand. His study supports the idea that various target languages and different reasons for learning can be considered as key motivational reasons (Duff, 2017). Findings of the present study also support the idea reported by Jin and Dewaele (2018). They concluded that foreign language anxiety is related not only to the learners' positive self-concept but also to their positive attitudes toward other people.

Table 7. Taxonomy for Individual Learner Differences

\begin{tabular}{|c|c|c|}
\hline Ehrman, Leaver, \& Oxford (2003) & Dornyei \& Skehan(2003) & Present Study \\
\hline $\begin{array}{l}\text { - learning styles } \\
\checkmark \text { Sensory differences } \\
\checkmark \text { Personality types } \\
\checkmark \text { Desired degree of generality } \\
\checkmark \text { Biological differences) (Oxford, 1990) }\end{array}$ & - Foreign language aptitude & $\begin{array}{l}\text { - Individuals' lack of } \\
\text { interest and motivation }\end{array}$ \\
\hline $\begin{array}{l}\text { - learning strategies } \\
\checkmark \text { Cognitive strategies } \\
\checkmark \text { Metacognitive strategies } \\
\checkmark \text { Socio-affective strategies } \\
\checkmark \text { (Oxford, 1990) }\end{array}$ & - Learning style & $\begin{array}{l}\text { - Individuals' lack of } \\
\text { English aptitude }\end{array}$ \\
\hline \multirow[t]{3}{*}{$\begin{array}{l}\text { - affective variables } \\
\checkmark \text { Motivation } \\
\checkmark \text { Self-efficacy } \\
\checkmark \text { Tolerance of ambiguity } \\
\checkmark \text { Anxiety }\end{array}$} & - Learning strategies & $\begin{array}{l}\text { - Individuals' lack } \\
\text { of sufficient time } \\
\text { to learn EFL }\end{array}$ \\
\hline & - Motivation & $\begin{array}{l}\text { - Individuals' absence } \\
\text { of 'need' to learn EFL }\end{array}$ \\
\hline & & $\begin{array}{l}\text { - Individuals' shyness } \\
\text { when speaking English }\end{array}$ \\
\hline
\end{tabular}




\section{Conclusion}

The purpose of the present study was to carry out a qualitative content analysis to explore factors affecting EFL learning, especially EFL speaking from the perspectives of EFL teachers and students in Iran. The saturation point was reached when the researcher ended conducting interviews with 10 EFL teachers and 12 university students. Data analysis revealed 640 open codes out of 950 primary codes which were finally condensed into 46 categories. The reduction continued as far as the researcher reached four main categories and finally one abstracted main theme. Table 8 below shows that the participants considered environmental, teacher characteristics, LPP, and individual learner differences as factors affecting EFL learning.

Table 8. Subcategories, Central Categories and Main Theme

\begin{tabular}{|c|c|c|}
\hline Main Theme & Categories & Subcategories \\
\hline \multirow{2}{*}{$\begin{array}{l}\text { INFLAMED } \\
\text { EFL } \\
\text { LEARNING }\end{array}$} & $\begin{array}{l}\text { Language } \\
\text { Planning } \\
\text { and Policy }\end{array}$ & $\begin{array}{l}\text { 1.1 Aging or maturational factors } \\
\text { 1.2 Inappropriate content of books } \\
\text { 1.3 Insufficient number of teaching hours } \\
\text { 1.4 Lack of supervision or monitoring of the teaching } \\
\text { and learning process by the relevant authorities } \\
\text { 1.5 Mere use of Persian texts in other courses } \\
\text { and ignoring the use of English books } \\
\text { 1.6 Ineffective or lack of training courses for EFL teachers } \\
\text { 1.7 Ignoring listening and speaking skills in acquisition order } \\
\text { 1.8 Gap between EFL learning resources/ } \\
\text { equipment and current needs of learners } \\
\text { 1.9 overlooked priorities: The vagueness of 'what should be } \\
\text { learned' and 'how should it be organized for teaching' }\end{array}$ \\
\hline & $\begin{array}{r}\text { 2. Teacher } \\
\text { Himself } \\
\text { (herself) }\end{array}$ & $\begin{array}{l}\text { 2.1 Poor or inappropriate teaching methods } \\
\text { 2.2 Use of force } \\
\text { 2.3 Inadequate knowledge or lack of strong } \\
\text { will to teach or speak English } \\
\text { 2.4 Lack of enough understanding of learners } \\
\text { 2.5 Learners' confusions due to teachers' different what? } \\
\text { 2.6 Inadequate teaching and failure to follow rubrics in university } \\
\text { 2.7 Mismatch of ESP books with different trends in a discipline } \\
\text { 2.8 Teachers' lack of creativity } \\
\text { 2.9 Emphasis on learners' local errors instead of global errors } \\
\text { 2.10 Use of traditional methods in both teaching and testing } \\
\text { 2.11 Absence of supplementary materials along with main course book } \\
\text { 2.12 Learners' bad memories for EFL learning }\end{array}$ \\
\hline
\end{tabular}




\begin{tabular}{|c|c|c|}
\hline Main Theme & Categories & Subcategories \\
\hline \multirow[t]{2}{*}{$\begin{array}{l}\text { INFLAMED } \\
\text { EFL } \\
\text { LEARNING }\end{array}$} & $\begin{array}{l}\text { 3. Environ- } \\
\text { mental/Social } \\
\text { Element }\end{array}$ & $\begin{array}{l}\text { 3.1 Lack of enough equipment and teaching aids } \\
\text { 3.2 Failure of national media to broadcast English programs } \\
\text { 3.3 Inability of national media to produce } \\
\text { English programs to fit the local culture } \\
\text { 3.4 Inappropriate perspective of English language } \\
\text { 3.5 Absence of standard and reputable language institutions } \\
\text { in all cities and if there are any, they are still problematic } \\
\text { 3.6 Non-standardized English language tests with improper goals } \\
\text { 3.7 Lack of tourists and the tourism industry } \\
\text { 3.8 Lack of familiarity with English language around them } \\
\text { 3.9 Lack of enough employment for English graduates } \\
\text { 3.10 Un-affordability of people to travel abroad } \\
\text { and prepare necessary facilities } \\
\text { 3.11 Confidence of EFL learners in successfully and } \\
\text { easily passing higher level English courses in future } \\
\text { 3.12 Lack of a supportive system for both teaching } \\
\text { and managing EFL learning programs } \\
\text { 3.13 Lack of a proper educational environment } \\
\text { especially in language institutes } \\
\text { 3.14 Overcrowded EFL classes } \\
\text { 3.15 Induction of the common view that English } \\
\text { is an alien language that is difficult to learn } \\
\text { 3.16 Available guidebooks make learners lazy }\end{array}$ \\
\hline & $\begin{array}{l}\text { 4. Learners' } \\
\text { Individual } \\
\text { Characteristics }\end{array}$ & $\begin{array}{l}\text { 4.1 Individuals' lack of interest and motivation } \\
\text { 4.2 Individuals' lack of English aptitude } \\
\text { 4.3 Individuals' lack of sufficient time to learn EFL } \\
\text { 4.4 Individuals' absence of 'need' to learn EFL } \\
\text { 4.5 Individuals' shyness when speaking English }\end{array}$ \\
\hline
\end{tabular}

The absence of the four mentioned factors leads to 'inflamed EFL learning'. The interviewees viewed environmental factors as the most influential factor and individual learner differences as the least important element. Teachers' characteristics and LPP were considered as the second and third important factor.

\section{Pedagogical Implications}

Decisions related to the present qualitative study will affect language planners and policymakers (LPP) and EFL teachers as well.

\section{Pedagogical Implications for Language Planners and Policymakers}

In order to develop a native-like accent, language planners and policymakers should be reminded that EFL learning should begin during a certain period of life, before puberty 
or even earlier (primary school); it will be more fruitful to start EFL learning from primary school.

Some conditions (maturational factors, inappropriate content of books, and insufficient number of teaching hours...) should be provided for relevant authorities to supervise and monitor both teaching and learning processes. Also, it is recommended that teaching two hours a week is not enough and will not lead to full mastery and proficiency. This necessitates increasing the number of teaching hours per week.

Since EFL teachers have different attitudes, methods, and techniques toward EFL teaching, some effective training courses should be provided to create a harmony among all of them. One of the most common questions in EFL pedagogy has been whether there is a ready and complete EFL method for all learners in all parts of the world. It can be answered with confidence that such a ready and complete method is not available. Of course, based on the experiences of different scholars and reviewing literature in this field, it can be claimed that one of the best methods is communicative language teaching. Kumaravadivelu's (2006) post-method, due to its needs analysis of learners and due to its three significant features of 'alternative to method', 'teacher autonomy', and 'principled pragmatism,' can also provide the possibility of teaching EFL practically and for a particular group of learners.

Social environment plays a major part in an individual's progress. Policymakers should be reminded that decisions related to factors such as EFL context, socio/economical supports, and teaching equipment are aspects that neither teachers nor students have control over and are within the authority of language planners and policymakers.

\section{Pedagogical Implications for EFL Teachers}

Factors associated with EFL teachers are another key aspect affecting EFL learning. In order to have successful EFL learning and teaching, teachers should be more innovative, creative, democratic, knowledgeable, and energetic.

EFL teachers must adopt an approach that makes learners more interested and aware of their need to learn English. However, as some participants in this study have mentioned, individual factors may be influenced by environmental factors, that is, the stress on

150 environmental factors and their enrichment can also lead to the strengthening of individual factors. They should employ a democratic approach and refrain from an authoritative classroom management. EFL teachers should have a high teaching commitment to teach according to the syllabus or rubric in the universities.

In short, in order to have effective teaching, foreign language teachers must consider all factors affecting EFL teaching, especially teaching the speaking skill. They should emphasize all four important factors affecting EFL teaching as those related to language planning and 
Inflamed EFL Learning: A Qualitative Study to Explore Factors Affecting EFL Learning

policy', 'teacher characteristics', 'environmental/social factors', and 'learners' individual factors', which are classified as the four main themes of this study. It is also recommended that all subcategories of the four main themes be considered in their teaching. Finally, among the four main themes of the study, teachers should pay special attention to environmental / social factors as one of the most important factors affecting EFL learning.

\section{References}

Afshar, H. S., \& Asakereh, A. (2016). Speaking skills problems encountered by Iranian EFL freshmen and seniors from their own and their English instructors' perspectives. Electronic Journal of Foreign Language Teaching, 13(1), 112-130.

Aghagolzadeh, F., \& Davari, H. (2017) English education in Iran: From ambivalent policies to paradoxical practices. In R. Kirkpatrick (Ed.), English language education policy in the Middle East and North Africa (pp.47-62). Springer.

Atkinson, D., \& Ramanathan, V. (1995). Cultures of writing: An ethnographic comparison of L1 \& L2 university writing/language program. TESOL Quarterly, 29(3), 539-568.

Bolderstone, A. (2012). Directed reading article: Conducting a research interview. Journal of Medical Imaging and Radiation Sciences, 43, 66-76.

Butler, Y. G., \& Le, V. N. (2018). A longitudinal investigation of parental social-economic status (SES) and young students' learning of English as a foreign language, System (73), 4-15.

Canale, M., \& Swain, M. (1980). Theoretical bases of communicative approaches to second language teaching and testing. Applied Linguistics, 1, 1-47.

Chen, J. (2012). Favorable and unfavorable characteristics of EFL teachers perceived by university students of Thailand. International Journal of English Linguistics, 2(1), 213-219.

Cresswell, J. W. (2003). Qualitative, quantitative, and mixed method approaches (2 ${ }^{\text {nd }}$ ed.). Sage.

de Burgh-Hirabe, R., (2019). Motivation to learn Japanese as a foreign language in an Englishspeaking country: An exploratory case study in New Zealand. System, 80, 95-106.

Derwing, T. M., Decorby, E., Ichikawa, J., \& Jamieson, K. (1999). Some factors that affect the success of ESL high school students. The Canadian Modern Language Review, 55(4), 532-547.

Donato, R., \& Terry, R. M. (1995) (Eds.). Foreign language learning: The journey of a lifetime. National Textbook Co.

Dornyei, Z., \& Skehan, P. (2003). Individual differences in second language learning. In C. J. Doughty \& M. H. Long. (Eds.), The handbook of second language acquisition (pp. 589-631). Blackwell Publishing.

Duff, P. A. (2017). Commentary: Motivation for learning languages other than English in an English-dominant world. The Modern Language Journal, 101(3), 597-607.

Ehrman, M. E., Leaver, B. L., \& Oxford, R. (2003). A brief overview of individual differences in second language learning, System, 31, 313-330. 
Ellis, R. (1994). The study of second language acquisition. Oxford University Press.

Elo, S., \& Kyngas, H. (2008). The qualitative content analysis. Advanced Nursing, 62(1), 107-115.

Farhady, H., Hezaveh, F. S., \& Hedayati, H. (2010). Reflections on foreign language education in Iran. TESL-EJ, 13(4), 1-18.

Fathman, A. K. (1976). Variables affecting the successful learning of English as a second language. TESOL Quarterly, 4(10), 60-68.

Hancock, B. (2002). Trent focus group: An introduction to qualitative research. University of Nottingham.

Hsieh, H. F., \& Shannon, S. E. (2005). Three approaches to qualitative content analysis. Qualitative Health Research, 15(9), 1277-1288.

Hymes, D. (1971). On Communicative competence. University of Pennsylvania Press.

Iranmehr, A., \& Davari, H. (2018). English language education in Iran: A site of struggle between globalized and localized versions of English. Iranian Journal of Comparative Education, 1(2), 70-84.

Jin, Y. X., \& Dewaele, J. M. (2018). The effect of positive orientation and perceived social support on foreign language classroom anxiety. System, 74, 149-157.

Kumaravadivelu, B. (2006). Understanding language teaching from method to post method. Lawrence Erlbaum Associates.

Kovács, Á. (2011). The role of social environment in the formation of adult English language learners' attitudes to learning English: A pilot study. WoPaLP, 5, 100-117.

Krefting, L. (1991). Rigor in qualitative research: The assessment of trustworthiness. The American Journal of Occupational Therapy, 45(3), 214-222.

Kvale, S. (2007). Doing interviews. Sage.

Li, D. (2001). Teachers' perceived difficulties in introducing the communicative approach in South Korea. In R. Hall \& A. Hewings (Eds.), Innovation in English language teaching (pp. 149-169). Routledge.

Liando, Nihta V. F. (2010). Students vs. teachers' perspectives on best teacher characteristics in EFL classrooms. TEFLIN Journal, 21(2), 118-136.

Lincoln, Y. S., \& Guba, E. G. (1985). Naturalistic inquiry. Sage Publications.

Lincoln, Y. S., \& Guba, E. G. (2000). Paradigmatic controversies, contradictions and emerging confluences. In N. K. Denzin \& Y. S. Lincoln (Eds.), Handbook of qualitative research, (2 ${ }^{\text {nd }}$ ed.). Sage Publications.

Macalister, J. (2018). Professional development and the place of journals in ELT. RELC Journal, $49(2), 238-256$.

Mack, N., Woodsong, C., MacQueen, K. M., Guest, G., \& Namey, E. (2005). Research methods: A data collector's field guide. Family Health International.

Mahmoudikia, M., \& Ahmadi, A. (2020). Iranian university instructors' perception on Englishmajoring students' speaking needs: A case of Shiraz university English department. Iranian Journal of English for Academic Purposes, 9(4), 15-30. 
Morse, J. M. (1994). Critical issues in qualitative research methods. Sage Publications.

McNamara, C. (2009). General guidelines for conducting interviews. Retrieved January 22, 2013, from http://managementhelp.org/evaluatn/intrview.htm/

Niu, R., Lu, K., \& You, X. (2018). Oral language learning in a foreign language context: Constrained or constructed? A sociocultural perspective. System, 74, 38-49.

Nunan, D. (1992). Research methods in language learning. Cambridge University Press.

Oxford, R. L. (1990). Language learning strategies: What every teacher should know. Newbury House.

Sadeghi, K., \& Richards, J. (2015). Teaching spoken English in Iran's private language schools: Issues and options. English Teaching: Practice and Critique, 14(2), 210-234.

Schumin, K. (2002). Factors to consider: Developing adult EFL students' speaking abilities. In J. C. Richards \& W. A. Renandya (Eds.), Methodology in language teaching: An anthology of current practice (pp. 204-212). Cambridge University Press.

Tesch, R. (1990) Qualitative research: Analysis types and software tools. Palmer, PA.

Turner, D. W. (2010). Qualitative interview design: A practical guide for novice investigators. The Qualitative Report, 15(3), 754-760.

Webster, S. (2019). Understanding lack of development in early career teachers' practical knowledge of teaching speaking skills. System, 80, 154-164.

Wong, Sh. D. (1996). Institutional policies and language minority students. TESOL Quarterly, 30(3), 583-591.

Woods, P. (2006). Qualitative research. University of Plymouth.

Zhang, Y., \& Wildemuth, B. M. (2009). Unstructured interviews. In B. Wildemuth (Ed.), Applications of social research methods to questions in information and library science (pp. 222-231). Libraries Unlimited. 